DOI. 10.22219/fths.v4i2.16502

\title{
Formulation and Antioxidant Test of Baby Instant Porridge with Kepok Banana Flour and Tempe
}

\author{
Sukardi ${ }^{1}$, Selvy Triskiana Wista ${ }^{1}$, Vritta Amroini Wahyudi ${ }^{*}$ \\ ${ }^{1}$ Food Technology Department, Faculty of Agriculture and Animal Science, University of \\ Muhammadiyah Malang, Malang, 65145, Indonesia \\ *Corresponding author email: vritta@umm.ac.id
}

\begin{abstract}
Commercial instant porridge generally chooses to use rice flour as a carbohydrate source, including instant porridge specifically for babies. The high current consumption of rice is encouraging various food diversification efforts to avoid dependence on one commodity. Kepok banana flour can be used as a substitute for carbohydrates in instant baby porridge, mainly from rice flour and tempe as a source of protein. Banana leaves and teak leaves were chosen as a wrapper for tempe to affect the chemical and organoleptic properties of instant baby porridge. The purpose of this study was to obtain instant baby porridge products which have nutritional value according to the SNI 01-71111.1-2005 standards regarding complementary foods. This study used a completely randomized design (CRD), consist of tempe packaging, namely banana leaves and teak leaves, which were carried out three times using the pairwise difference test (t-test) as a statistical test. Instant baby porridge with tempe treatment packed with banana leaves is an instant baby porridge that is closest to SNI 01-7111.1-2005 concerning complementary feeding with a moisture content value of $18.89 \%$, ash content $2.71 \%$, protein content $6.66 \%$, fat content $16.96 \%$, carbohydrate content $54.77 \%$, $76.70 \%$ antioxidant activity, and the highest preference level with a value of 4.87
\end{abstract}

Keywords: banana flour, banana leaves, instant baby porridge, teak leaves, tempe

\section{INTRODUCTION}

The complimentary food for breast milk (complementary feeding) is food given to infants or children in addition to breast milk to meet nutritional needs (Mufida et al., 2015). According to the Decree of the Minister of Health No. 224/MENKES/SK/II/2007 concerning Technical Specifications of complementary feeding, complementary feeding (In Bahasa : SK Menteri Kesehatan No. 224/MENKES/SK/II/2007 tentang Spesifikasi Teknis complementary feeding) in the form of porridge given to children aged 7-12 months. Commercial instant porridge generally uses rice flour as a carbohydrate source, including instant porridge specifically for babies. The high rice consumption currently encourages various kinds of food diversification efforts to avoid dependence on one commodity (Yustiyani and Setiawan, 2013). 
The baby porridge is usually made of millet flour and mung bean flour (Husna et al., 2012), arrowroot flour, and red bean flour (Tamrin and Pujilestari, 2016). This study proposes an update on flour from banana kepok and tempe, commonly used as daily food.

Kepok banana was chosen in this study because it is familiar in Indonesian society as a fruit given as food to babies. Kepok banana can be used as a substitute for carbohydrate sources in instant baby porridge, mostly rice flour. Kepok banana is rich in minerals such as potassium, magnesium, phosphorus, iron, and calcium. Banana fruit also contains high carbohydrates and has a high enough nutritional value as a source of calories, vitamins and minerals as well as fiber, so it is suitable for digestion (Handoyo, 2019, Rangkuti et al., 2015, Yani et al., 2013, Kiswandono, 2019).

Tempe is recently wrapped in plastic. Plastics contain plasticizers or materials that are added to the manufacture of plastics to get the desired plastic character (Voidarou et al., 2021, Kaur et al., 2021). Phthalate and bisphenol-A compounds are several types of compounds used in the manufacture of plastics and have been studied to be leached from plastic and evaporate into the environment (Hahladakis et al., 2018, Huysman et al., 2019). Therefore, tempe in this study was packaged using natural ingredients in the form of banana leaves and teak leaves to reduce the impact of using plastic on food ingredients. Banana leaves contain catechins which are one of the aroma-producing compounds (Sahaa et al., 2013) while teak leaves contain B-carotene which is a natural pigment source of antioxidants (Vyas et al., 2019).

Tempe needs to be added to this study as a substitute for instant baby porridge to add protein content. The nutritional content of tempe has been researched and proven to have a high enough nutrient content and is easily digested and absorbed by the human body. The fermentation process that occurs in tempe increases free amino acids from $7.3 \%$ to $30 \%$, which is caused by the performance of Rhizopus and bacteria to produce protease enzymes that can break down protein into free amino acids (Purry and Rafiony, 2019). The presence of flavor compounds in the ester, terpenoids, alcohol, aldehyde, ketone, furan, and nitrogen-containing compounds in tempe packed with banana leaves (Harahap et al., 2018).

The expectation in this research is to get instant baby porridge with nutritional value according to SNI standards and flavor that can be accepted by the panelists. This research was conducted by analyzing water content, ash content, protein content, fat content, carbohydrate content, antioxidant activity, and oranoleptic tests to obtain physicochemical and organoleptic properties. 


\section{RESEARCH METHOD}

\section{Materials}

The main ingredients used in this study were fresh kepok bananas (local market), fresh soybeans (local market), banana leaves (Karang Ploso Malang), teak leaves (Landung Sari Malang), tempe yeast, skim milk, sugar, olive oil extract. pure, and mineral water. Chemical reagents used include distilled water, DPPH solution (2,2-diphenyl-1-pikrilhidrazil), technical ethanol (96\%), petroleum benzene p.a, $\mathrm{NaOH}$ p.a, Biuret solution, and BSA (Bovine Serum Albumin).

\section{Equipment}

The tools used in the process of making instant baby porridge products include scales, steamer pans, stoves, thermometers, pans, spoons, spatulas, bowls, blenders, and filters. The tools used in the analysis process include porcelain crucibles, fat flasks, soxhlets, beaker cups, erlenmeyers, measuring flasks, spatulas, stirring rods, test tubes, measuring cups, measuring pipettes, filler pipettes, cuvettes, Pioneer Ohaus type analytical scales. Glaswerk Wertheim type 6132 desiccator, caliesys PLC series centrifuge, oven (Romand type 50), UV-Vis spectrophotometer (Shimadzu), and Thermostat Water Bath (type HH-4).

\section{Making Tempe}

Tempe was made using a wet peel method based on a modified Syarief et al. (1999): soybeans that have been washed and cleaned soaked for 22 hours are dehulling from the skin and washed then boiled at $100^{\circ} \mathrm{C}$ for 30 minutes. The next stage is giving a starter of tempe as much as $0.5(\% \wedge(\mathrm{w} / \mathrm{b}))$ and wrapped in 2 kinds of packaging (banana leaves and teak leaves). Yeast that has been previously grown on soybeans (as a starter, called "usar" in Bahasa) is done based on Koswara et al. (2000) by placing teak/banana leaves on top of the bamboo with the bottom surface facing upwards. The prepared soybeans are spread on each leaf surface and then covered with teak/banana leaves with the soybeans' bottom surface. Each pair of plates was wrapped in perforated plastic and allowed to stand (ferment) for 24 hours at room temperature $\left(25^{\circ} \mathrm{C}\right)$.

\section{Making Kepok Banana Flour}

Banana flour is made based on the modified Perezsira (1997) method: Ripe banana trees characterized by 1 or 2 yellow fruits. The fruit is peeled and then sliced into $1 \mathrm{~cm}$ size using a sharp knife. The fruit slices were placed on pans and dried in a cabinet dryer at $50^{\circ} \mathrm{C}$ for 48 hours. The final stage is the flouring process using a grinder to produce banana flour. 


\section{Making Instant Baby Porridge (Tamrin and Pujilestari, 2016 with Modification)}

The formulations used are Kepok banana flour, tempe extract, skim milk, sugar, and olive oil with a ratio of 30:30:30:5:5 (\%). All ingredients are mixed and then cooked at $75{ }^{\circ} \mathrm{C}$ for 10 minutes until well blended. Furthermore, the slurry is flattened on a baking sheet to be dried in an oven at $60^{\circ} \mathrm{C}$ for 1 hour. The dried pulp is then blended and sieved with a size of 80 mesh.

\section{Research Design}

This study used a simple completely randomized design (CRD) with a single factor in soybean tempe packaging, namely banana leaves, and teak leaves. The treatment was carried out three times so that the total sample analyzed was 6 samples with analysis in the form of moisture content, ash content, protein content, fat content, carbohydrate content, antioxidant activity of the DPPH method, and organoleptics in the form of appearance, texture, taste and preferences.

\section{Parameter Analysis}

Instant baby porridge, kepok banana flour substituted for tempe, packed with banana leaves and teak leaves, was analyzed for proximate (Harini et al., 2019) such as moisture content, ash content, fat content (AOAC, 2005); protein analysis (Indrawan, 2016); analysis of carbohydrate levels by difference (Winarno, 2004); DPPH method of antioxidant activity analysis (Molyneux, 2004); and organoleptic analysis in the form of appearance, texture, taste, and preferences (Rahayu, 2001).

\section{Data Analysis}

The data obtained were analyzed with various fingerprint (ANOVA) at $\alpha=$ $5 \%$ and followed by Duncan's Multiple Range Test (DMRT).

\section{RESULT AND DISCUSSION}

\section{Proximate Analysis}

The instant baby porridge from the research results was tested for its chemical content, such as water content (\%), ash content (\%), protein content (\%), lipid content (\%), and carbohydrate content (\%) (Figure 1). 


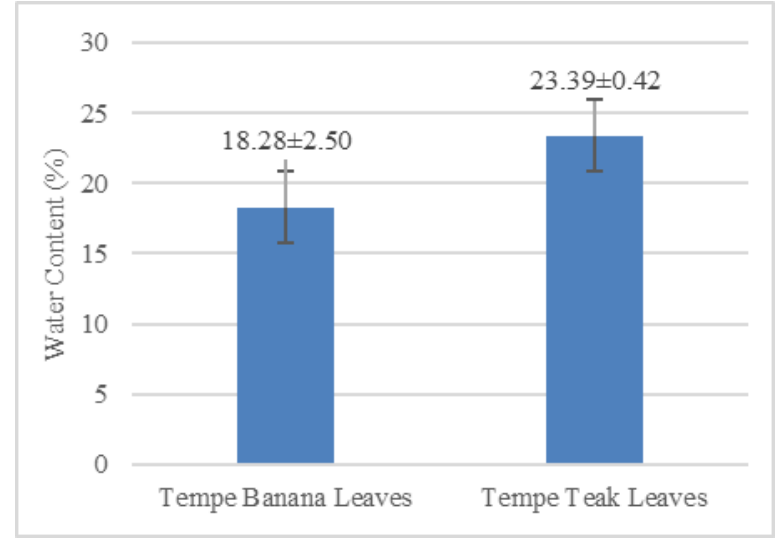

(a)

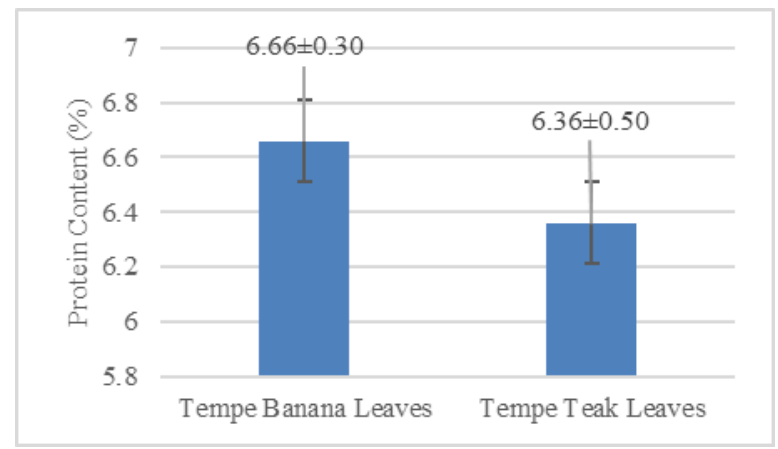

(c)

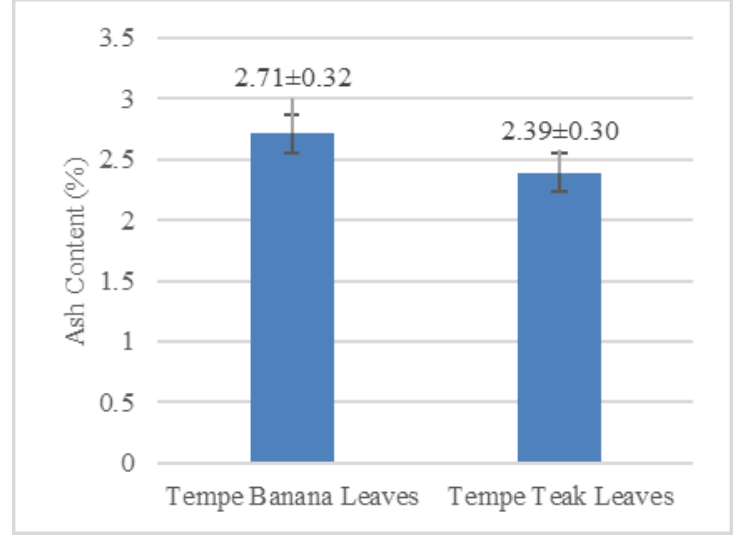

(b)

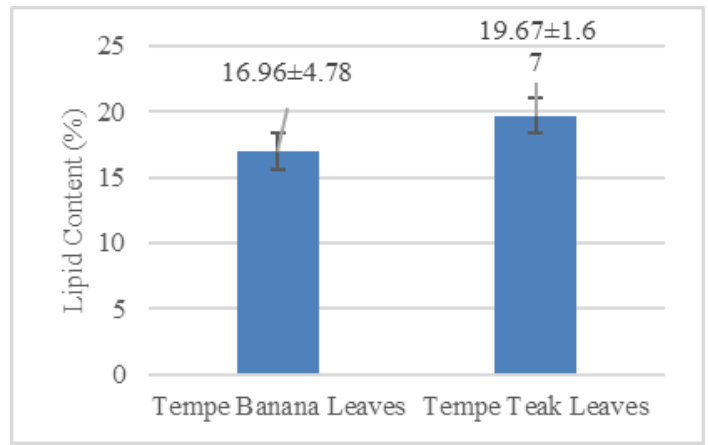

(d)

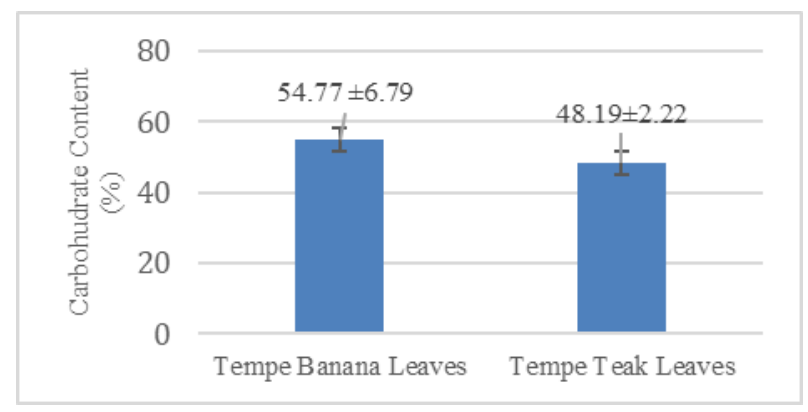

(e)

Figure 1. The Proximate Analysis Result of Instant Baby Porridge Based on Different Types of Tempe (a) Water Content, (b) Ash Content, (c) Protein Content, (d) Lipid Content, (e) Carbohydrate Content

\section{Water Content Analysis}

Based on the results of further analysis, it is known that the different types of tempe packaging have no significant difference in moisture content. The water content in a food material greatly affects the storage capacity and quality of the food material. The average results of instant baby porridge water content ranging from $18.89 \%-23.39 \%$. All formulations of instant baby porridge from banana and tempe flour have a high water content. The quality standard of complementary feeding (SNI 01-7111.1-2005) indicates that the water content in $100 \mathrm{~g}$ of 
complementary feeding does not exceed $4 \mathrm{~g}$. Due to the high water content, it is assumed that the shelf-life of instant baby porridge is shorter than the commercial instant baby porridge, which meets SNI standards. This is because the high water content will provide a medium for the growth of microorganisms. The high water content in baby instant porridge can be caused by the high protein contained in the ingredients of the pulp, namely tempe, besides the tempe processing process in the pulp which only goes through one drying process so that the water content in the tempe is still quite high. The high protein content in food ingredients can increase the binding power to the water. The higher the protein content, the higher the water content (Doster et al., 2010). This result is similar to previous research that tempe flour and pumpkin flour in the manufacture of instant baby porridge resulted in moisture content of $4.26 \%-6.52 \%$ with the first flour process on tempe ingredients (Tampubolon, 2014).

\section{Ash content}

Based on the different analyses, it can be seen that the different types of tempe packaging have an ash content that is not significantly different. The average yield of instant baby porridge ash content was $2.39-2.71 \%$. Following SNI 01-7111.1-2005 concerning instant baby porridge, the ash content is not more than $3.5 \%$. Measurement of ash content aims to determine the amount of mineral content contained in instant baby porridge. The ash content of a material is related to the mineral content in the material (Harini et al., 2019). The different types of tempe packaging do not affect the ash content produced. The ash content contained in $100 \mathrm{~g}$ of tempe is $4.3 \mathrm{~g}$ (Dwinaningsih, 2010). Tempe contains sufficient amounts of macro and micro minerals. The number of minerals iron, copper, and zinc. Tempe mold can produce phytase enzymes that break down phytic acid (which binds several minerals) into phosphorus and inositol. With the breakdown of phytic acid, certain minerals (such as iron, calcium, magnesium, and zinc) become more available for the body to use (Alvina and Hamdani, 2019). In addition, the ash content of instant baby porridge is also influenced by the nutritional content of skim milk. The amount of minerals in skim milk is also high, consisting of 1300 $\mathrm{mg}$ of calcium, $1030 \mathrm{mg}$ of phosphorus, and $0.6 \mathrm{mg}$ of iron (Mufida et al., 2015).

\section{Protein Content}

Based on the different analyses, it can be seen that the different types of tempe packaging have the results of protein content that are not significantly different. Protein content in instant baby porridge ranges from $6.66-6.36 \%$. This shows that the protein content in instant baby porridge formulation of banana and tempe flour does not meet the SNI 01-7111.1-2005 standards regarding instant 
complimentary feeding powder; namely, the protein content must range from 8$22 \%$ in $100 \mathrm{~g}$. Proteins are natural polymers composed of various amino acids which contain elements $\mathrm{C}, \mathrm{H}, \mathrm{O}$, and $\mathrm{N}$, which are not owned by fat or carbohydrates. Protein molecules contain phosphorus, sulfur, and types of proteins containing metal elements such as iron and copper (Zhang et al., 2021). The raw material for making instant baby porridge has a high enough protein content. Previous research stated that the protein content in the leaf-wrapped tempe was $44.77 \%$, and the plastic-wrapped tempe was $41.38 \%$ (Salim, 2017). Decreased or denatured protein levels are thought to occur due to the heating process carried out on the ingredients (Li et al., 2021). The tempe goes through a branching process with a temperature of $90^{\circ} \mathrm{C}$ for 10 minutes, then mixing all ingredients (including banana flour and skim milk) at $80^{\circ} \mathrm{C}$ for 10 minutes, then drying at $60^{\circ} \mathrm{C}$ for 30 minutes. The results that the heating process in tempe can reduce protein levels by $1.37 \%$ (Salim, 2017).

\section{Lipid Content}

Based on the different analyses, it can be seen that the different types of tempe packaging have the results of fat content that are not significantly different. The average yield of instant baby porridge fat content was $16.96-19.67 \%$. This shows that the fat content contained is more significant than SNI 01-7111.1-2005 concerning instant complimentary feeding powder, namely the fat content ranges from $6-15 \mathrm{~g}$ in $100 \mathrm{~g}$ of ingredients. The high-fat content is caused by the raw material for making instant baby porridge.

\section{Carbohydrate Content}

Based on the different analyses, it can be seen that the different types of tempe packaging produce carbohydrate content that is not significantly different. The average result of the carbohydrate content of instant baby porridge was 54.77$48.19 \%$. The carbohydrate content of commercial instant porridge is higher than the carbohydrate content of instant porridge based on banana and tempe flour. This corresponds to previous research that kepok banana peel was known that carbohydrate content kepok banana is $18.50 \%$ (Setiawati et al., 2013), carbohydrate content of tempe $34.4 \%$ (Ferreira et al., 2011).

\section{Antioxidant Activity}

Based on the different analyses, it can be seen that the different types of tempe packaging have the results of antioxidant activity that are not significantly different. The average yield of antioxidant activity in instant baby porridge was $76.70-88.42 \%$ (Figure 2). The high antioxidant activity in instant baby porridge can 
be caused by the raw material for making instant baby porridge, namely tempe. In soybean, there are three types of isoflavones, namely daidzein, glycitein, and genistein. In tempe, besides the three types of isoflavones, antioxidant factor II (6,7,4-trihydroxy isoflavones) has the most potent antioxidant properties compared to the isoflavones soybeans. These antioxidants are synthesized during the fermentation process of soybeans into tempe by micrococcus luteus and coreyne bacterium (Bintari and Parman, 2019, Astuti et al., 2000, Li et al., 2020, Rashad et al., 2011).

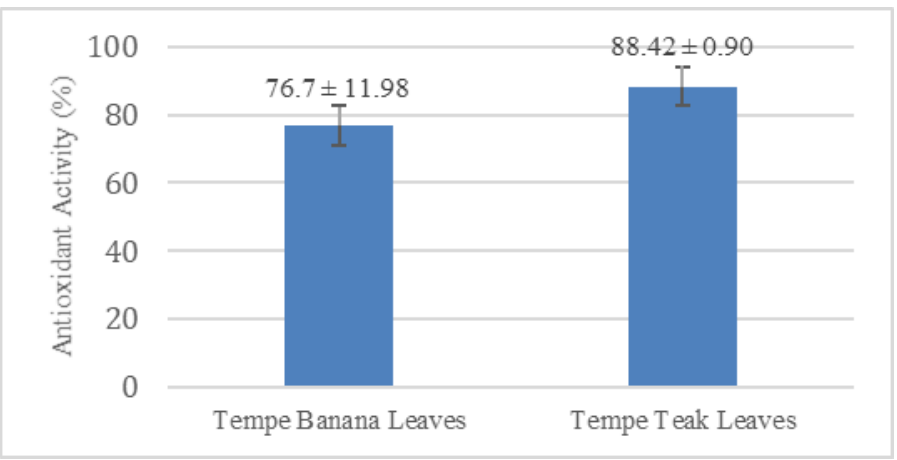

Figure 2. The Antioxidant Activity of Instant Baby Porridge Based on Different Types of Tempe

\section{Organoleptic Analysis (SNI, 2002)}

The instant baby porridge resulted from the research was analyzed its organoleptic aspects: appearance, texture, taste, and favorite (Figure 3). The analysis was carried out with a scale of 1-7 (from unattractive to very interesting).

\section{Appearance (SNI, 2002)}

Based on the different analyses, it can be seen that the differences in tempe packaging have organoleptic results that are significantly different. The type of tempe packaging has a significant effect on the appearance of instant baby porridge. The panelists' organoleptic scores on the appearance of instant baby porridge ranged from 4.27 to 4.93 , which means that the average panelists rated the appearance of instant baby porridge as somewhat interesting. In the opinion of the panelists, the preferred appearance is that of bright yellowish color. The color of the instant pulp for each formula is quite the same, namely brownish yellow, but in the instant baby porridge, banana, and tempe flour packed with teak leaves has a darker color. Teak leaves have one natural pigment, namely Bcarotene, a carotenoid compound (Fathinatullabibah et al., 2014). This pigment affects the color of the instant baby porridge. The formulation of tempe, which is packed with teak leaves, becomes darker. 


\section{Texture (SNI, 2002)}

Based on the different analyses, it can be seen that the differences in tempe packagings have an organoleptic texture that is not significantly different. The type of tempe packaging has no significant effect on the texture of instant baby porridge. The organoleptic score of the panelists on the texture of instant baby porridge ranged from 3.93 to 4.33 , which means that the average panelist assessing the texture of instant baby porridge was rather coarse. In the quality standard of complementary feeding by SNI 01-7111.1-2005, it is indicated that the form of complementary feeding can be in the form of powder or granule. In contrast, for the texture of complementary feeding, when added with liquid, it produces a fine pulp, free from lumps, and can be fed with a spoon. The high water content in instant baby porridge causes bumps in the instant baby porridge so that the resulting texture is a bit rough.

\section{Taste (SNI, 2002)}

Based on the different analyses, it can be seen that the differences in tempe packaging have organoleptic results that are not significantly different. The type of tempe packaging has no significant effect on the taste of instant baby porridge. The organoleptic score of the panelists on the taste of instant baby porridge ranged from 4.60-5.00. The taste of instant baby porridge is caused by ingredients in products such as banana flour, tempe, sugar, and skim milk. The banana taste is the most dominant because the banana used in the manufacture of banana flour is ripe kapok banana. As bananas ripen, the sweetness increases because the sucrose content in bananas increases. During the ripening process of banana fruit, starch is converted into sugar through an enzymatic process where there is a decrease in the starch content from $20-30 \%$ to $1-2 \%$, followed by an increase in the amount of sugar content, main sucrose to more than $10 \%$ by weight of fresh fruit (Imaduddin and Susanto, 2017).

\section{Favorite (SNI, 2002)}

Based on the different analyses, it can be seen that the differences in tempe packagings have a preference organoleptic result that is not significantly different. The type of tempe packaging has no significant effect on the preference for instant baby porridge. The organoleptic score of the panelists on the importance of instant baby porridge ranged from 4.53 to 4.87 , which means that, on average, the panelists rated instant baby porridge rather like it. The preference test assesses all observed quality factors, including appearance, texture, and taste. This test is intended to determine the level of panelist acceptance of a product. Based on the results of the hedonic test on overall acceptance, it shows that instant baby 
porridge using banana flour and tempe packed with banana leaves has the highest value, meaning that instant baby porridge is the most preferred by the panelists.

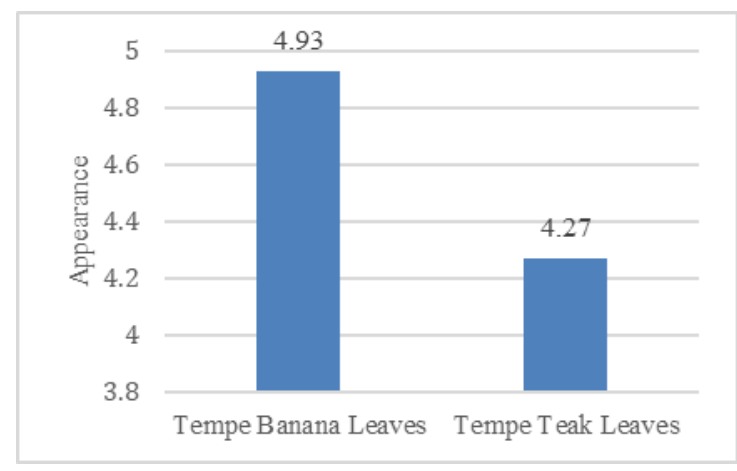

(a)

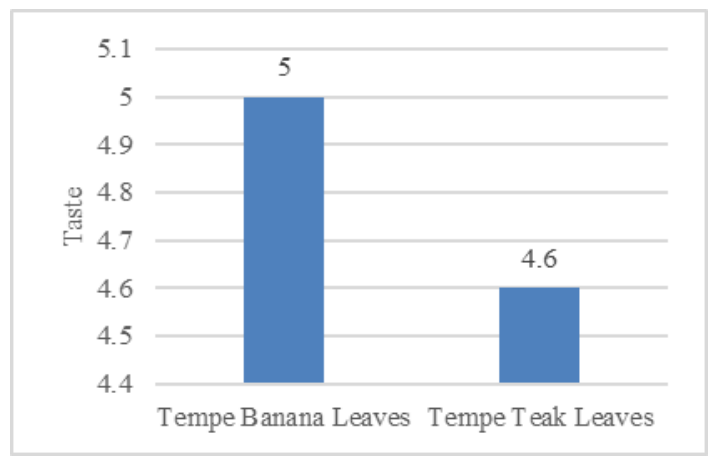

(c)

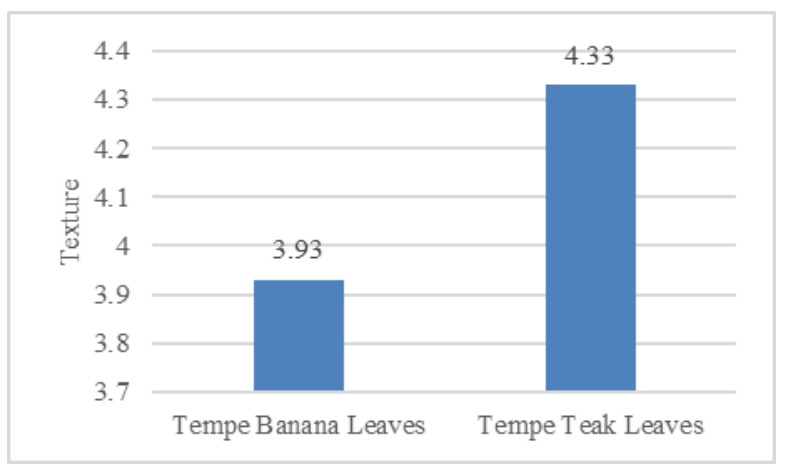

(b)

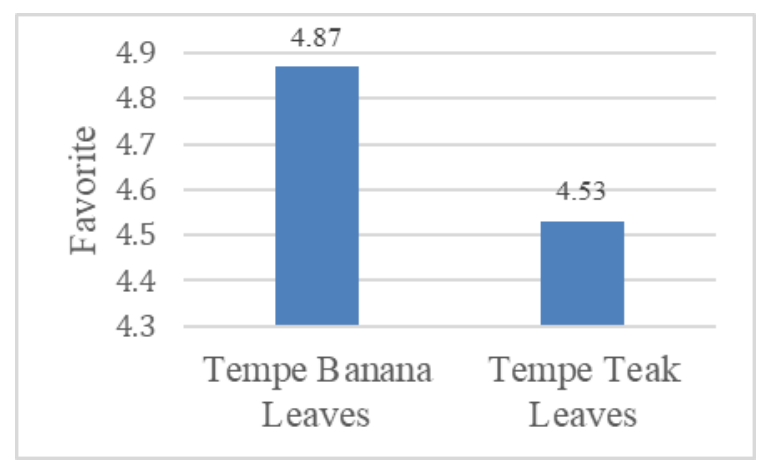

(d)

Figure 3. Organoleptic Analysis Result of Instant Baby Porridge Based on Different Types of Tempe (a) Appearance, (b) Texture, (c) Taste, (d) Favorite

Comparison of Research Results of Instant Baby Porridge with SNI 01 7111.1-2005 Comparison of the nutritional value of complementary foods from SNI 017111.1-2005 with the results of proximate analysis (moisture content, ash content, protein content, fat content, and carbohydrate content) in instant baby porridge from Kepok banana flour with tempe substitution results from fermented teak leaves and Banana leaves can be seen in Table 1. 
Table 1. Comparison of Results of Instant Baby Porridge Analysis with SNI

\begin{tabular}{lccccc}
\hline \multicolumn{1}{c}{ Treatment } & $\begin{array}{c}\text { Water } \\
\text { Content } \\
(\%)\end{array}$ & $\begin{array}{c}\text { Ash } \\
\text { Content } \\
(\%)\end{array}$ & $\begin{array}{c}\text { Protein } \\
\text { Content } \\
(\%)\end{array}$ & $\begin{array}{c}\text { Lipid } \\
\text { Content } \\
(\%)\end{array}$ & $\begin{array}{c}\text { Carbohydrate } \\
\text { Content (\%) }\end{array}$ \\
\hline Tempe Banana Leaves & $18.89 \%$ & $2.71 \%$ & $6.66 \%$ & $16.96 \%$ & $54.77 \%$ \\
Tempe Teak Leaves & $23.39 \%$ & $2.39 \%$ & $6.36 \%$ & $19.67 \%$ & $48.19 \%$ \\
Indonesian Standard (SNI) & $\leq 4 \%$ & $\leq 3.5 \%$ & $8-22 \%$ & $6-15 \%$ & - \\
\hline
\end{tabular}

Table 1 shows that the water content in instant baby porridge is much higher than SNI for complementary feeding. This can be caused by the processing of tempe in the pulp, which only goes through one drying process so that the water content in the tempe is still relatively high. Due to the high water content, it is assumed that the shelf-life of instant baby porridge is shorter than the commercial instant baby porridge, which meets the SNI standards for complementary feeding. This is because the high water content will provide a medium for the growth of microorganisms. Ash content in instant baby porridge in this study has met the SNI standard for complementary feeding. Protein content produced by instant baby porridge in this study does not meet SNI standards. This is a deficiency because protein is an essential nutritional component for infant intake. Decreased or denatured protein levels are thought to occur due to the heating process carried out on the ingredients (Alvina \& Hamdani, 2019). Heating causes denaturation of the destruction of the protein structure so that the protein will settle. The fat content in instant baby porridge in this study is higher than SNI. This is due to the fat content of the material relatively high, namely from the raw materials of tempe and olive oil. There are no requirements regarding the range of carbohydrate content in the SNI complementary feeding.

\section{CONCLUSION}

The different types of tempe packaging affect the water content and appearance of instant baby porridge. They do not affect the ash content, protein content, fat content, carbohydrate content, antioxidant content, organoleptic taste, texture, and preferences. Instant baby porridge from Kepok banana flour with tempe substitution fermented teak leaves and banana leaves has not yet entered the SNI standards regarding water content, protein content and fat content. Still, it is already following SNI on ash content and carbohydrate content. Instant baby porridge with tempe treatment packed with banana leaves is instant baby porridge that is closest to SNI 01-7111.1-2005 regarding complementary feeding with a moisture content value of $18.89 \%$, ash content $2.71 \%$, protein content $6.66 \%$, fat 
content $16.96 \%$, carbohydrate content $54.77 \% 76.70 \%$ antioxidant activity, and the highest preference level with a value of 4.87 .

\section{REFERENCES}

Alvina, A. \& Hamdani, D. H. 2019. Proses Pembuatan Tempe Tradisional. Jurnal Ilmiah Pangan Halal, 1 (1), pp. 1-4. doi: 10.30997/jiph.v1i1.2004.

Astuti, M., Meliala, A., Dalais, F. S. \& Wahlqvist, M. L. 2000. Tempe, a nutritious and healthy food from Indonesia. Asia Pacific Journal of Clinical Nutrition, 9 (4), pp. 322-325. doi: 10.1046/j.1440-6047.2000.00176.x.

Azni, I. N. 2019. Formulasi Bahan Makanan Campuran Berbahan Dasar Kedelai, Beras Merah, Dan Pisang Kepok Untuk Makanan Pendamping-Asi. Jurnal Teknologi Pangan dan Kesehatan (Journal of Food Technology And Health), 1 (1), pp. 1-7. doi: 10.36441/jtepakes.v1i1.164.

Bintari, S. \& Parman, S. Antioxidant capacity and nutritional value of tempe yogurt. Journal of Physics: Conference Series, 2019. IOP Publishing, 032048, pp.1-5. doi: 10.1088/1742-6596/1321/3/032048

Doster, W., Busch, S., Gaspar, A. M., Appavou, M.-S., Wuttke, J. \& Scheer, H. 2010. Dynamical transition of protein-hydration water. Physical review letters, 104 (9), pp. 1-5. doi: 10.1103/PhysRevLett.104.098101

Dwinaningsih, E. A. 2010. [Bachelor Thesis]. Karakteristik kimia dan sensori tempe dengan variasi bahan baku kedelai/beras dan penambahan angkak serta variasi lama fermentasi.

Fathinatullabibah, F., Khasanah, L. U. \& Kawiji, K. 2014. Stabilitas antosianin ekstrak daun jati (Tectona grandis) terhadap perlakuan $\mathrm{pH}$ dan suhu. Jurnal Aplikasi Teknologi Pangan, 3 (2), pp. 60-64.

Ferreira, M. P., Oliveira, M. C. N. D., Mandarino, J. M. G., Silva, J. B. D., Ida, E. I. \& Carrão-Panizzi, M. C. 2011. Changes in the isoflavone profile and in the chemical composition of tempe during processing and refrigeration. Pesquisa agropecuária brasileira, 46 (1), pp. 1555-1561. doi: 10.1590/S0100$204 X 2011001100018$.

Hahladakis, J. N., Velis, C. A., Weber, R., Iacovidou, E. \& Purnell, P. 2018. An overview of chemical additives present in plastics: migration, release, fate and environmental impact during their use, disposal and recycling. Journal of hazardous materials, 344 (1), pp. 179-199. doi: 10.1016/j.jhazmat.2017.10.014. Epub 2017 Oct 9.

Handoyo, J. P. 2019. [Phd Thesis]. Diversification of "Kepok" Banana Flour (Musa paradisiaca L.) AS Kaastengels. Unika Soegijapranata Semarang.

Harahap, R. H., Lubis, Z. \& Kaban, J. 2018. Volatile Flavor Compounds of Tempe Wrapped With Banana Leaf and Plastic. AGritech-Jurnal Teknologi Pertanian, 38 (1), pp. 194-199. doi: 10.22146/agritech.24720.

Harini, N., Renita Marianty, S. \& Wahyudi, V. A. 2019. Analisa Pangan, Zifatama Jawara.

Husna, E. A., RakhmawantI, D., Kawiji, K. \& Anandito, R. B. K. 2012. Karakterisasi Bubur Bayi Instan Berbahan Dasar Tepung Millet (Panicum sp) dan Tepung Kacang Hijau (Phaseolus radiatus) Dengan Flavor Alami 
Pisang Ambon (Musa paradisiaca var. Sapientum 1.). Jurnal Teknosains Pangan, 1 (1), pp. 68-74.

Huysman, S., Van Meulebroek, L., Janssens, O., Vanryckeghem, F., Van Langenhove, H., Demeestere, K. \& Vanhaecke, L. 2019. Targeted quantification and untargeted screening of alkylphenols, bisphenol A and phthalates in aquatic matrices using ultra-high-performance liquid chromatography coupled to hybrid Q-Orbitrap mass spectrometry. Analytica Chimica Acta, 1049, pp. 141-151. doi: 10.1016/j.aca.2018.10.045.

Imaduddin, A. H. \& Susanto, W. H. 2017. Pengaruh Tingkat Kematangan Buah Belimbing (Averrhoa carambola L.) dan Proporsi Penambahan Gula terhadap Karakteristik Fisikokimia dan Organoleptik Lempok Belimbing. Jurnal Pangan dan Agroindustri, 5 (2), pp. 45-57.

Kaur, S., Kaur, R., Rani, N., Sharma, S. \& Joshi, M. 2021. Sources and Selection Criteria of Probiotics. Advances in Probiotics for Sustainable Food and Medicine, pp. 27-43. doi: 10.1007/978-981-15-6795-7_2.

Kiswandono, K. K. 2019. [Bachelor Thesis]. Product Development OF Sponge Cake Based on Banana "Kepok" Flour (Musa paradisiaca L.). Unika Soegijapranata Semarang.

Li, J., Wang, K., Gao, Y., ma, C., SuN, D., Hussain, M. A., Qayum, A., Jiang, Z. \& Hou, J. 2021. Effect of thermal treatment and pressure on the characteristics of green soybean tofu and the optimization conditions of tofu processing by TOPSIS analysis. LWT, 110314 (136), pp. 1-8. doi: 10.1016/j.lwt.2020.110314.

Li, S., Jin, Z., Hu, D., Yang, W., Yan, Y., Nie, X., Lin, J., Zhang, Q., Gai, D. \& Ji, Y. 2020. Effect of solid-state fermentation with Lactobacillus casei on the nutritional value, isoflavones, phenolic acids and antioxidant activity of whole soybean flour. LWT, 109264 (125), pp. 1 - 8. doi: 10.1016/j.lwt.2020.109264.

Mufida, L., Widyaningsih, T. D. \& Maligan, J. M. 2015. Prinsip Dasar Makanan Pendamping Air Susu Ibu (MP-ASI) Untuk Bayi 6-24 Bulan: Kajian Pustaka [In Press September 2015]. Jurnal Pangan dan Agroindustri, 3 (4), pp. $1646-1651$.

Purry, A. P. K. \& Rafiony, A. 2019. Pembuatan Minuman Sari Tempe dengan Ekstrak Jeruk Siam (Citrus nobilis)Ditinjau dari Mutu Organoleptik Kadar Vitamin C dan Kadar Aktivitas Antioksidan Isoflavon. Pontianak Nutrition Journal (PNJ), 1 (1), pp. 60-65. doi: 10.30602/pnj.v1i2.289.

Rangkuti, N., Yuliana, Y. \& Holinesti, R. 2015. Pengaruh Substitusi Tepung Pisang Kepok terhadap Kualitas Cookies. E-Journal Home Economic and Tourism, 9.

Rashad, M. M., Mahmoud, A. E., Abdou, H. M. \& Nooman, M. U. 2011. Improvement of nutritional quality and antioxidant activities of yeast fermented soybean curd residue. African Journal of Biotechnology, 10 (1), pp. 5504-5513.

Sahaa, R. K., Acharyaa, S., Shovon, S. S. H. \& Royb, P. 2013. Medicinal activities of the leaves of Musa sapientum var. sylvesteris in vitro. Asian Pacific 
journal of tropical biomedicine, 3 (1), pp. 476-482. doi: 10.1016/S22211691(13)60099-4.

Salim, R. 2017. Analisis jenis kemasan terhadap kadar protein dan kadar air pada tempe. Jurnal Katalisator, 2 (1), pp. 106-111. doi: 10.22216/jk.v2i2.2531

Setiawati, D. R., Sinaga, A. R. \& Dewi, T. K. 2013. Proses Pembuatan bioetanol dari kulit pisang kepok. Jurnal Teknik Kimia, 19 (1), pp. 9-15.

Tampubolon, N. L. 2014. Formulasi Bubur Bayi Instan dengan Substitusi Tepung Tempe dan Tepung Labu Kuning sebagai Alternatif Makanan Pendamping ASI. Jurnal Rekayasa Pangan dan Pertanian, 2(2), pp. 78-83.

Tamrin, R. \& Pujilestari, S. 2016. Karakteristik bubur bayi instan berbahan dasar tepung garut dan tepung kacang merah. Jurnal Konversi, 5 (1), pp. 49-58. doi: $10.24853 /$ konversi.5.2.49-58.

Utari, D. M. 2010. Kandungan Asam Lemak, Zink, dan Copper pada Tempe, Bagaimana Potensinya untuk Mencegah Penyakit Degeneratif? Gizi Indonesia, 33(2), pp. 108-115 . doi: 10.36457/gizindo.v33i2.87.

Voidarou, C., Antoniadou, M., Rozos, G., Tzora, A., Skoufos, I., Varzakas, T., Lagiou, A. \& Bezirtzoglou, E. 2021. Fermentative Foods: Microbiology, Biochemistry, Potential Human Health Benefits and Public Health Issues. Foods, 10 (1), pp. 6-9. doi: 10.3390/foods10010069.

Vyas, P., Yadav, D. K. \& Khandelwal, P. 2019. Tectona grandis (teak)-A review on its phytochemical and therapeutic potential. Natural product research, 33 (1), pp. 2338-2354. doi: 10.1080/14786419.2018.1440217.

Yani, A., Wylis Arief, R. \& Mulyanti, N. 2013. Processing of banana flour using a local banana as raw materials in Lampung. International Journal on Advanced Science, Engineering and Information Technology, 3 (1), pp. 289293. doi: 10.18517/ijaseit.3.4.306.

Yustiyani, Y. \& Setiawan, B. 2013. Formulasi Bubur Instan Menggunakan Komposit Tepung Kacang Merah dan Pati Ganyong sebagai Makanan Sapihan. Jurnal Gizi dan Pangan, 8 (1), pp. 95-102. doi: 10.25182/jgp.2013.8.2.95-102.

Zhang, X., Zhang, S., Xie, F., Han, L., Li, L., Jiang, L., Qi, B. \& Li, Y. 2021. Soy/whey protein isolates: interfacial properties and effects on the stability of oil-in-water emulsions. Journal of the Science of Food and Agriculture, 101 (1), pp. 262-271. doi: 10.1002/jsfa.10638. 